Vol. 5 No. 3 (2021) pp. 224 - 231

Available online at: http://jurnal.umpwr.ac.id/index.php/abdimas/index

p-ISSN: 2580-3492 e-ISSN: 2581-0162

\title{
English Learning Assistance in the Era Pandemic COVID-19 for Students in Mendiro
}

\section{Sudar, Semi Sukarni $\varangle$, Junaedi Setiyono, Zulia Chasanah, Juita Triana}

\section{Universitas Muhammadiyah Purworejo}

Jl. KH. A. Dahlan 3 Purworejo, 54111, Jawa Tengah, Indonesia

| semisukarni@umpwr.ac.id $ه \mid$ DOI : https://doi.org/10.37729/abdimas.v5i3.1164 |

\begin{abstract}
Abstrak
This paper aims to provide information about English learning assistance in the era pandemic Covid-19 for students in Mendiro through the community service. This activity was done to respond the community's need to minimize the problems of learning English which were appeared during Covid-19 pandemic. The participants of the activity were 25 students which consisted of primary schools, Junior High School and Senior High School. The main problem of the students were difficulties in understanding English lessons as they were lack of interaction with their teachers since they were study from home (BDR). They have limited strategies to do self study at home. To overcome the problems, a team of lecturers of English Language Education conducted a community service in Mendiro village, Ngombol subdistric of Purworejo. Through sharing of knowledge and strategies to learn English skills through internet media, the participants could get knowledge and took opportunity to practice their English. By adopting the strategies given by team of lecturers, the participants are expected to be able to learn English easier with more enjoyable and enjoy simple literary works such as short films, short stories, short stories videos and songs. Finally, they can obtain better English skills in the future.

Kata Kunci: Learning assistance, English skills, COVID-19 pandemic
\end{abstract}

(c) () (9) This work is licensed under a Creative Commons Attribution-NonCommercial 4.0 International License

\section{Introduction}

The Covid-19 pandemic occurred and spread to more than 200 countries, influencing most people all over the world, social life, human life, business, education, and many other aspects. During the COVID-19 pandemic, more than 60 million students across the country have been forced to study from home for months. However, online learning presents new challenges, particularly with uneven access to technology and inadequate online teaching methods, and there is growing concern that remote learning may exacerbate educational inequalities (the jakarta post). The Covid-19 pandemic occurred and spread to more than 200 countries, influencing most people all over the world, social life, human life, business, education, and many other aspects.

During the COVID-19 pandemic, more than 60 million students across the country have been forced to study from home for months. However, online learning presents new challenges, particularly with uneven access to technology and inadequate online teaching methods, and there is growing concern that remote learning may exacerbate educational inequalities by the Indonesian Children Protection Commission (KPAI) in https://en.tempo.co. This happened as students have to learn learning materials by themselves, do abundance assignments given by teachers by themselves, 
they have also to submit them by themselves as they have no interaction with friends or ask questions to their teachers.

Some studies had been reported related to the practice of online learning of English subject during Covid-19. Firstly, studies about readiness, obstacles, difficulties, challenges, and perceptions of online learning were conducted by Mahyoob (2020), Nartiningrum \& Nugroho (2020), Ariyanti (2020), Nugraha, Nurlestari \& Salma Siti Maryam (2021) and Efriana (2021). During the COVID-19 Pandemic, Mahyoob researched the Challenges of e-Learning. According to EFL Learners, the main problems that influence and impact online EFL learning during COVID-19 are related to technical, academic, and communication challenges; most EFL learners are dissatisfied with continuing online learning because they did not make the expected progress in language learning performance. Furthermore, Nartiningrum and Nugroho (2020) stated that online learning did not function properly during the COVID-19 pandemic. Many students were unprepared to respond to a problem with online learning. Concerned with the perception of online learning During the COVID-19 Pandemic, Mahyoob researched the Challenges of e-Learning. According to EFL Learners, the main problems that influence and impact online EFL learning during COVID-19 are related to technical, academic, and communication challenges; most EFL learners are dissatisfied with continuing online learning because they did not make the expected progress in language learning performance.

Other research findings provide ideas, solution or some ways to make the online learning or distance learning to be beneficial to students. This need the adoption of technology to make the distance learning become meaningful to learners. Some studies related to maximixing the benefits of distance learning had been conducted by Apriyanti, Syarif, Ramadhan, Zaim, \& Agustina (2019), Kara (2019), Brazenas (2019), Zeng (2020) and Ghounane (2020). Kara (2019) contributes a syllabus framework mediated by Google Education to the field of teaching English as a second/foreign language. The requirement for relevance effort, such as bridging the ever-widening gap between the classroom and the digital world of web 2.0 learners. Zeng (2020) discusses language learning with online technologies, with a particular emphasis on the social web's influence on language learning. According to Apriyanti et al. (2019), Google Classroom has increased efficiency and effectiveness in the process of teaching and learning in an English Business Writing class. According to Brazenas (2019), the mediabased adaptation of a popular student-centered activity was largely positive, with students remarking on improved learning autonomy, oral communication skills, and cultural awareness. Furthermore, observations and class artifacts revealed high participation rates and overall engagement with the activity. Ghounane's (2020) research on Moodle or Social Networks for Learning revealed that students are motivated to use both SNSs like Facebook and YouTube and educational platforms like Moodle as complementary teaching materials. Research in more specific area related to the learning of English subject which cover listening, speaking, reading and writing by young and middle learners. Among them were conducted by Alsubaie \& Ashuraidah (2017), Martínez-carrasco (2018), Nee, Yunus, \& Suliman (2019), D. T. Öztürk \& Tekin (2020), Maru et al. (2020), (Romero-villamil \& Guzman-martinez, 2020). Alsubaie and Ashuraidah (2017) reported a significant increase in student scores when using Google Docs. Furthermore, the findings were consistent in that students saw Google Docs as a useful tool for both individual and group work. Furthermore, Nee, Yunus, and Suliman (2019) concluded that ICT and social media help to promote writing skills among students, particularly those learning English as a second language. In terms of listening, 
Oztürk and Tekin (2020) demonstrated that all of the participants in their study exhibited a positive tendency toward listening and improved their level of listening skill, as well as some other skills in the target language with listening worksheets. Maru et al. (2020) found that the mean score of the post-test is significantly higher than that of the pre-test in their study on using video for writing descriptive text in EFL class and examining whether the videos can develop students' ability in writing descriptive text or not. This demonstrates the effectiveness of using video to teach descriptive text writing. Another use of video was emphasized in (Romero-villamil and Guzman-martinez"s, 2020) study, who reported that the participants found the videos useful for remembering new words and being able to use them in communicative contexts.

By referring to the facts, problems in global era during Covid-19 pandemic faced by the students who learn English, the writers would like to adopt previous research result to identify problem faced by student in Mendiro and try to find solution or minimize the problem of learning English during covid-19 pandemic by conducting community service with a theme "English Learning Assistance in the Era Pandemic Covid-19 for Students in Mendiro".

\section{Method}

\subsection{Time and Place of Community Service}

The activity of "English Learning Assistance in the Era Pandemic Covid-19 for Students in Mendiro" was held on Saturday, 3 ${ }^{\text {rd }}$ April 2021 in the Village Hall of Mendiro, Ngombol Subdistric, Purworejo. Mendiro is one of the small village in Ngombol subdistric which is relatively quite far from the town of Purworejo.

\subsection{Subject of Community Service}

The participants of "English Learning Assistance in the Era Pandemi Covid-19 for Students in Mendiro" were the students which consisted of students of primary schools, Junior High School and Senior High School with total participants was 25.

\subsection{Procedure}

Before conducting the Community Service, the team had tried to identify some problems by observing the location and did short interview with the village leader related to the practice of online learning during Covid-19 for the students in the village. Here are the problem which could be identified:

a. Lack of understanding of English materials, both listening, reading speaking and writing, due to limited interactions with teachers at school.

b. Students are not sure whether the assignments that have been done are right or wrong because of the lack of feedback from the teacher.

c. Lack of knowledge on the use of media and home learning strategies (BDR) to learn English for listening and reading.

d. There is no modeling in practicing English, especially speaking.

e. Students wish to develop English language skills but do not know the methods and strategies. 
To help solving the problems faced by students, the lecturers of English Language Education of Muhammadiyah Purworejo University community service team would collaborate with the village leader and residence to share knowledge, deliver methods, strategies and follow with offering of consultations on effective English learning strategies to students in Mendiro.

Several fields of study that can be conveyed at the service session are as follows.

a. Strategies for learning to read with digital online text

b. Writing learning strategies with internet media.

c. Strategy to learn speaking using downloded video of speech from you tobe.

d. Strategies to develop vocabulary with internet media.

e. Strategies of understanding and writing literature using internet media.

Solving problems in learning English is expected to be able to help students improve their knowledge and skills as well as better attitudes in English learning so that they can improve their English skills and learning outcomes of English subject in school improve.

\section{Result and Discussion}

The implementation of this Community Service activity is intended to assist students in solving English learning problems in the Covid pandemic era. The English Material presentation was conveyed by the team of community service of English Language Education lecturers namely Dr. Sudar, M.Pd, Dr. Semi Sukarni, M.Pd., Dr Junaedi Setiyono, M.Pd and Juita Triana, M.Pd. who are expert in their subject areas. The point of emphasis of this activity is on English learning assistance so that students can master the knowledge and skills of English during the Covid-19 period by utilizing the internet media.

The results of this activity can be described one by one as follows: (a) participants are able to understand and apply strategies for learning to read with digital text on the internet; (b) participants know and apply writing learning strategies with internet media; (c) participants know and apply the strategy to learn speaking using video media that has been downloaded from youtube; (c) participants know and are able to apply learning strategies to develop vocabulary with internet media; (d) participants know and are able to apply learning strategies understanding and writing literature using internet media. Material presentation shown on Figure 1.
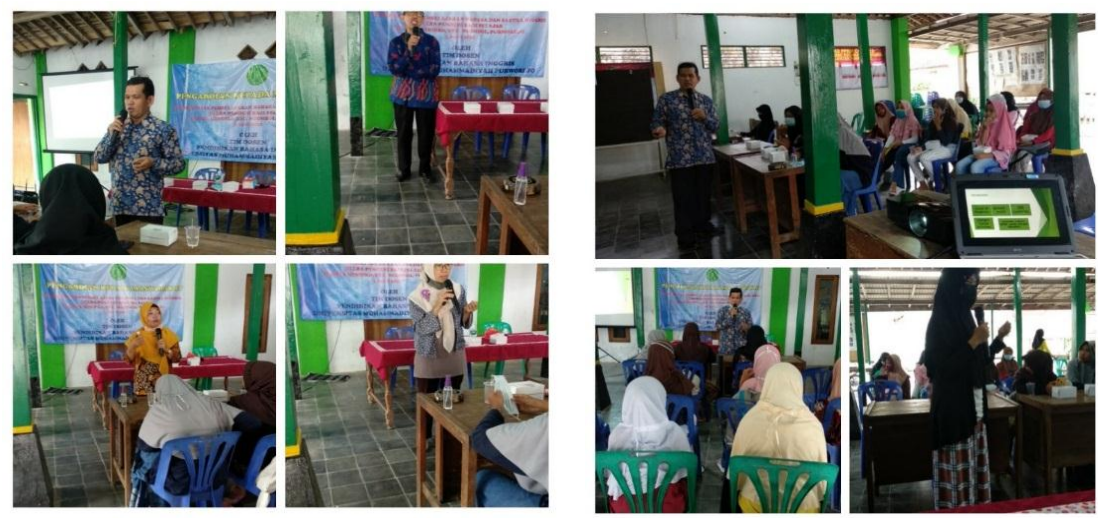

Figure 1: Material Presentation 
The implementation of this community servise can be explained in detail as follows.

\subsection{Strategies for learning to read with digital online text}

Students can employ metacognitive reading strategies such as global strategies, problem-solving strategies, and support strategies. Global strategies are those used to manage one's own reading process, such as checking the text's length, determining whether the text is written appropriately in terms of its objectives, determining whether an appropriate language is used in the text in terms of its register, having a reason to read the text, and so on. Problem-solving strategies are associated with the steps taken when dealing directly with the text. Support strategies refer to the outside assistance and assistance that readers and learners receive, such as the use of a dictionary, translation, highlighting, making notes on the page's margins, and so on. (Sheorey and Mokhtari in S. Y. Öztürk, 2018).

\subsection{Writing learning strategies with internet media.}

By adopting friendly learning platforms and social media such as you tobe, instagram, google classroom and wikis the learners could practice writing with more ideas and better contents as it was shown in Martínez-carrasco (2018), Nee et al. (2019) and Maru et al. (2020).

\subsection{Strategy to learn speaking using downloded speech video from you tobe}

The learners participants can develop their speaking competence through downloded video of speech from you tobe which have English sub-title. They listen and at the same time they see how the words and phrases are pronounced as they can be downloaded from English speech you tobe. Besides laerning some important aspects and techniques of public speaking, they can also learn their body language and expressions. To explore more on public spaeking they can read books from Davidson (2002), (Fraleigh \& Tuman, 2005), and (German, Gronbeck, Ehninger, \& Monroe, 2016).

\subsection{Strategies to develop vocabulary through internet media}

The learner participants can learn the strategies for buliding vocabulary by making use of the internet such as online texts, online newspaper, authentic materials such as advertisements, captions, etc. by reading, reading, and reading; keep a dictionary and thesaurus close at hand; Make your own dictionary; learn a new word every day; and play some games. participate in discussions. Other books can be used to explore for strategies for learning vocabulary such as Suter (2004) or Nadler, Nadler, \& Nadler (2005).

\subsection{Strategies of understanding and writing literature in the internet}

The learner participants can learn the strategies of understanding and writing literature using internet media. By adopting the medium of children literature such as short stories, short story videos with English subtitle and songs, learners can easily understand and perform writing, imitating the stories, singing or speaking about literary appreciation as it was reported by Abdelhalim (2015). 


\section{Conclusion}

Based on the results of the feedback, it was found that this activity was very relevant to the needs of the participants. They feel they have got applicable and useful insights and skills. In addition, they also feel happy with the mentoring techniques and strategies that are applied during the activity with great hospitality and sanity. The abilities that are trained and possessed by the participants are: (1) Knowledge of learning strategies for learning English and developing language skills, especially reading, writing, speaking as well as understanding and enjoying child-friendly literary works such as songs, short stories, short story videos with subtitles and short films; (2) Participants can do problem sharing about the difficulties of learning English during the pandemic and get responses and be followed up with mentoring activities in learning English. Given the importance of learning English in improving 21st century competence, students are expected to be able to use the English learning strategies that have been delivered by the Community Service Team. By applying the techniques and strategies, it is hoped that the participants will find it easier and more enjoyable in learning English and it is hoped that their mastery of English can be improved. It is suggested that learners can follow up to take advantage of learning resources other than teachers and the media in consultation with English lecturers at the Muhammadiyah University of Purworejo who are ready to provide learning assistance during the pandemic.

\section{Acknowledgement}

The author would like to thank the Institute for Research and Community Service through internal grants for service funds, as well as the Mendiro village government, Ngombol sub-district who are willing to be partners for this community service

\section{Reference}

Abdelhalim, S. M. (2015). Children literature based program for developing EFL primary pupils' life skills and language learning strategies. English Language Teaching, 8(2), 178-195. https:// doi.org/10.5539/elt.v8n2p178

Alsubaie, J., \& Ashuraidah, A. (2017). Exploring Writing Individually and Collaboratively Using Google Docs in EFL Contexts, 10(10). https://doi.org/10.5539/elt.v10n10p10

Apriyanti, D., Syarif, H., Ramadhan, S., Zaim, M., \& Agustina, A. (2019). TechnologyBased Google Classroom In English Business Writing Class, 301(Icla 2018), 689-694. https:/ / doi.org/10.2991/icla-18.2019.113

Ariyanti, A. (2020). EFL Students' Challenges towards Home Learning Policy During Covid-19 Outbreak. IJELTAL (Indonesian Journal of English Language Teaching and Applied Linguistics), 5(1), 167. https:// doi.org/10.21093/ijeltal.v5i1.649 
Brazenas, A. J. (2019). Media Circles in the EFL Classroom: Furthering Student Engagement. THAITESOL Journal, 32(2), 65-85. Retrieved from http:/ / ezproxy.uow.edu.au/login?url=https:// search.ebscohost.com/login.aspx? direct $=$ true $\& \mathrm{db}=$ eric $\& A N=E J 1245535 \&$ site $=$ ehost-live

Davidson, J. (2003). The Complete Guide to Public Speaking. Canada: John Wiley \& Sons, Inc.

Efriana, L. (2021). Problems of Online Learning during Covid-19 Pandemic in EFL Classroom and the Solution. Journal of English Language Teaching and Literature, 2(1), 38-47.

Fraleigh \& Tuman. (2005). Speak Up.

German, K. M., Gronbeck, B. E., Ehninger, D., \& Monroe, A. H. (2016). Principles of Public Speaking. Principles of Public Speaking. Taylor and Francis. https:/ / doi.org/10.4324/9781315506258

Ghounane, N. (2020). Moodle or Social Networks: What Alternative Refuge Is Appropriate to Algerian EFL Students to Learn during COVID-19 Pandemic. Arab World English Journal, 11(3), 21-41. Kara, S. (2019). Learning autonomy, digital learners and Google Education: a rhizomatic English syllabus framework. The EuroCALL Review, 27(1), 30. https://doi.org/10.4995/eurocall.2019.10709

Mahyoob, M. (2020). Challenges of e-Learning during the COVID-19 Pandemic Experienced by EFL Learners. Arab World English Journal, 11(4), 351-362. https://doi.org/10.24093/awej/vol11no4.23

Martínez-carrasco, R. (2018). Social media in L2 education: exploring on-line collaborative writing in EFL settings, (2018), 17-26.

Maru, M. G., Manado, U. N., Nur, S., Makassar, U. N., Lengkoan, F., \& Manado, U. N. (2020). Applying Video for Writing Descriptive Text in Senior High School in the Covid-19 Pandemic Transition, 4(3), 408-419.

Nadler, B. J., Nadler, J., \& Nadler, J. (2005). Burton Jay Nadler, Jordan Nadler, Justin Nadler - Words you should know in high school_ 1,000 essential words to build vocabulary, improve standardized test scores, and write successful papers (2005, Adams Media).pdf.

Nartiningrum, N., \& Nugroho, A. (2020). Online Learning amidst Global Pandemic: EFL Students' Challenges, Suggestions, and Needed Materials. ENGLISH FRANCA: Academic Journal of English Language and Education, 4(2), 115. https:// doi.org/10.29240/ef.v4i2.1494

Nee, C. C., Yunus, M., \& Suliman, A. (2019). ICT: An Effective Platform to Promote Writing Skills among Chinese Primary School Pupils, 10(4), 223-237.

Öztürk, D. T., \& Tekin, S. (2020). Encouraging Extensive Listening in, 14(2010), 80-93.

Öztürk, S. Y. (2018). European Journal of Foreign Language Teaching USE OF METACOGNITIVE ONLINE READING STRATEGIES BY STUDENT TEACHERS OF ENGLISH, 3(3), 17-32. https:/ / doi.org/10.5281/zenodo.1297197

Romero-villamil, J. L., \& Guzman-martinez, C. P. (2020). Learning Vocabulary Through Instructional Aprendizaje de Vocabulario a través de, 21(21), 7-25. 
Ryan Agustian Nugraha1 Syifa Dwi Nurlestari2 Salma Siti Maryam. (2021). EFL LEARNING CHALLENGES IN THE MIDS OF COVID-19 PANDEMIC: A CASE OF SENIOR HIGH SCHOOL STUDENTS. In Proceeding (p. 6).

Suter, J. (2004). Building Vocabulary: Skills \& Strategies, Level 3. United States of America: Saddleback Educational Publishing.

Zeng, S. (2020). The Potential of Online Technology for Language Learning, 13(10), 2337. https:/ / doi.org/10.5539/elt.v13n10p23

https:// www.thejakartapost.com/news/2020/07/19/distance-learning-threatens-toexacerbate-education-inequality-in-indonesia.html. Accessed on 18 May, 2021. https://en.tempo.co/read/1368434/kpai-says-many-students-stress-over-onlinelearning. Accessed on 18 May, 2021. 